\title{
SESTSTSis:
}

\section{Analysis of diversity and genetic interactions of potato varieties (Solanum tuberosum L.) based on morphological characteristics and SSR markers}

\author{
L. M. Prysiazhniuk ${ }^{1 *}$, O. L. Klyachenko ${ }^{2}$, I. O. Dikhtiar ${ }^{1}$, N. V. Symonenko ${ }^{1}$ \\ ${ }^{1}$ Ukrainian Institute for Plant Variety Examination, 15 Henerala Rodymtseva St., Kyiv, 03041, Ukraine, \\ *e-mail: prysiazhniuk_l@ukr.net \\ ${ }^{2}$ National University of Life and Environmental Sciences of Ukraine, 15 Heroiv Oborony St., Kyiv, 03041, Ukraine
}

Purpose. To estimate a correlation between SSR-markers and morphological features by genetic distances on the basis of polymorphism of potato varieties. Methods. PCR analysis, cluster and correlation-regression analysis. Results. The results of analysis of potatoes varieties polymorphism based on molecular genetic and morphological marker features are presented. Varieties polymorphism was assessed on four microsatellite markers: STM0019, STM3009, STM3012, STM5136 and 42 morphological markers. According to the results of PCR analysis, it was determined that the frequency of identified alleles ranged from 0.021 to 0.33 , the index of polymorphism on the average for studied markers was 0.76 . Using cluster analysis, the genetic distances between varieties based on SSR and morphological markers were determined, and simila$r$ varieties and varieties that differ among themselves were identified. According to the obtained distribution, the correlation between the genetic distances by Mantel test are estimated, namely, a regression, in which the variables are similarity matrices, summing the pairwise similar values between the sampling points was defined. As a result of the estimation of genetic distances between the investigated genotypes of potatoes, it was revealed that the varieties 'Skarbnytsia' and 'Yavir' were the most similar by markers STM0019, STM3009, STM3012, STM5136. The distance between these varieties was 2.45, while the greatest distance - 3.74 was found among the varieties 'Levada' and 'Dovira', 'Fantaziia' and 'Dovira'. According to marker morphological signs, the least value of genetic distances was 8.9 for varieties 'Slovianka' and 'Poliske Dzherelo', the most distant ones were '0kolytsia' and 'Dovira', with values of 18.2. It was revealed that the potato variety 'Dovira' with the value of genetic distances of 18.2 and 3.74 for morphological and SSR markers respectively was the most distant from other investigated genotypes. The correlations were not found by Mantel test as a result of the analysis of genetic distances based on SSR-markers and morphological signs. Conclusions. The use of a complex of studies containing a description of morphological features and microsatellite markers is promising for identifying potato varieties, creating collections of well-known varieties and determining their differences.

Keywords: potatoes; genetic polymorphism; cluster analysis; Mantel test; correlation links.

\section{Introduction}

Potatoes (Solanum tuberosum L.) is the main source of nutrition in many regions of the world and characterized by high levels of carbohydrates, proteins and vitamin $\mathrm{C}$ [1-3]. Genetic differentiation between individual genotypes or

Larysa Prysiazhniuk

http://orcid.org/0000-0003-4388-0485

Oksana Klyachenko

https://orcid.org/0000-0002-4087-4082

Iryna Dikhtiar (Sihalova)

http://orcid.org/0000-0001-7736-6121

Natalia Symonenko

https://orcid.org/0000-0002-9784-890X populations is evaluated at the level of quantitatively inherited phenotypic features, monogenic characteristics that are subjected to selective pressure (for example, signs of disease resistance), molecular markers, etc. Information on correlations that exist between different levels is important for several reasons. In particular, from an evolutionary point of view, the study of links between genetic diversity and morphological differentiation will help to find the mechanisms responsible for this differentiation. While from the standpoint of conservation of genetic resources - it promotes the search for similar signs of different genotypes or populations and combinations of genes, and predicts their heterosis based on selection [4-5]. Annually in 
Ukraine state testing for distinctness, uniformity and stability (DUS) of about 40 varieties of potatoes is held. At the same time, the increase in the number of new varieties introduced into production causes the need to control the diversity of modern varieties through reliable and modern methods for their differentiation.

Over the past thirty years, the results of the study of interaction between morphological features and DNA markers have been highlighted in a number of publications [6-8]. European organizations for plant variety evaluation, such as GEVES (France) and Naktuinbouw (the Netherlands), use the definition of correlations for the evaluation of new varieties and the formation of their collections [6, 8-12].

The purpose of the research is to assess the correlation between SSR markers and morphological features by genetic distances based on the polymorphism of potato varieties.

\section{Materials and methods}

Twelve varieties of potato selected at the Institute of Potato Studies of the National Academy of Sciences of Ukraine were studied: 'Poliske Dzherelo', 'Dorogyn', 'Oktolytsia', 'Dovira', 'Lileia', 'Levada', 'Yavir', 'Chervona ruta', 'Skarbnytsia', 'Obrii', 'Fantaziia' and 'Slovianka'.

The morphological features of potato varieties were described in the course of varieties testing for the purpose of their state registration. The DUS method numbers 42 marker signs of potato varieties, which cover the qualitative and quantitative characteristics of the sprouts grown by light, stems, leaves, buds, inflorescences and tubers. Varieties were evaluated using the method of visual assessment, measurements and calculations, depending on the type of signs detection using the DUS method [13]. According to the method, the degree of signs detection was denoted by numerical values from 1 to 9 . As a result of digital coding, matrices were constructed on which genetic distances were calculated.

DNA was isolated from two-week sprouts of $500 \mathrm{mg}$ potato varieties with CTAB (cetyltri- methylammonium bromide), purified with chloroform-isoamilic alcohol and precipitated with isopropyl alcohol [13-15]. Extracted DNA was stored at a temperature of $+4{ }^{\circ} \mathrm{C}$ during the process.

The molecular genetic polymorphism of potato varieties with specific primers: STM0019, STM3009, STM3012, STM5136 selected on the basis of the analysis of the polymorphic index $[12,14-17]$ (Table 1), was investigated based on four microsatellite loci (MC loci).

The reaction mixture contained $100 \mathrm{ng}$ DNA, the component concentration was: 1 Buffer (10 mM Tris-HCl, pH 9.0, $50 \mathrm{mM} \mathrm{KCl,} 0.01 \%$ Triton X-100), $2.5 \mathrm{mM} \mathrm{MgCl}_{2} ; 200 \mu \mathrm{M}$ deoxynucleotide triphosphates (dNTF), $0.5 \mu \mathrm{M}$ of each of the primers and 1 unit. act. Taq polymerase. The total volume of the mixture was $20 \mu \mathrm{L}$.

PCR (Polymerase Chain Reaction) was performed using the BioRad IQ5 (USA) amplifier. Parameter for amplification for the examined potato markers: initial denaturation $-95{ }^{\circ} \mathrm{C}-5$ minutes, 40 cycles: denaturation $-45 \mathrm{~s}$ for $95^{\circ} \mathrm{C}$, hybridization $-30 \mathrm{~s}$ for $50-60{ }^{\circ} \mathrm{C}$, elongation $90 \mathrm{~s}$ for $72{ }^{\circ} \mathrm{C}$, final elongation -7 minutes for $72{ }^{\circ} \mathrm{C}$. The visualization of the amplification reaction products was carried out by electrophoresis in a 4\% agarose gel in $0.5 \times$ TBE (tris borate buffer solution) according to the method $[15,20]$ for the intensity of the electric field of $5 \mathrm{~V} / \mathrm{cm}$. The size of ampilicons was determined using the TotalLab v.2.01 computer program.

On the basis of definite alleles, PIC (polymorphism information content) was calculated and binary data matrices were produced, with " 1 " for presence of the corresponding allele and " 0 " for its absence. The genetic distances between the studied varieties were determined using a computer program STATISCA 12 (trial version) based on cluster analysis. Varieties were grouped by SSR-markers with the use of unweighted pair-group method using arithmetic averages (UPGMA), by morphological features with the use of Single Linkage method with the calculation of Euclidean distances [21-24].

Characterization of SSR loci primers

\begin{tabular}{|c|c|c|c|c|c|}
\hline MC locus & $\begin{array}{c}\text { Primer sequence } \\
5^{\prime} \ldots \ldots \ldots 3^{\prime}\end{array}$ & GC-content, \% & Motif & $\begin{array}{l}\text { Hybridization } \\
\text { temperature, }{ }^{\circ} \mathrm{C}\end{array}$ & $\begin{array}{c}\text { Expected amplicon } \\
\text { size, bp }\end{array}$ \\
\hline \multirow{2}{*}{ STM0019 } & F - aataggtgtactgactctcatg & 39,1 & \multirow{2}{*}{$\begin{array}{l}\text { (AT)7, (AT)10, } \\
\text { (AT)4, (GT)5, } \\
\text { (GC)4, (GT)4 }\end{array}$} & \multirow{2}{*}{50} & \multirow{2}{*}{$99-206$} \\
\hline & R - ttgaagtaaaagtcctagtatgtg & 33,3 & & & \\
\hline \multirow{2}{*}{ STM3009 } & F-tcagctgaacgaccactgttc & 45,5 & \multirow{2}{*}{ (TC)13 } & \multirow{2}{*}{50} & \multirow{2}{*}{$110-140$} \\
\hline & $\mathrm{R}$ - gatttcaccaagcatggaagtc & 52,4 & & & \\
\hline \multirow{2}{*}{ STM3012 } & F- caactcaaaccagaaggcaaa & 42,9 & \multirow{2}{*}{$(\mathrm{GT}) 4,(\mathrm{CT}) 8$} & \multirow{2}{*}{60} & \multirow{2}{*}{$180-225$} \\
\hline & R-gagaaatgggcacaaaaaaca & 38,1 & & & \\
\hline \multirow{2}{*}{ STM5136 } & F-gggaaaaggaaaagctcaa & 42,1 & \multirow{2}{*}{$(A G A) 5$} & \multirow{2}{*}{60} & \multirow{2}{*}{$240-280$} \\
\hline & R - caacactatcgccatctccttt & 45,8 & & & \\
\hline
\end{tabular}


The correlation between the investigated SSR markers and the morphological characteristics of potato varieties was determined based on genetic distances using the Mantel test with XLSTAT 2018 computer program [25-26].

\section{Results}

Alleles of the expected size were obtained by PCR on four SSR markers with specific primers (Fig. 1).

According to obtained amplicons with STM3012 marker, 12 alleles of sizes 175-224 bp were identified among the studied varieties. For the other investigated loci from five (markers STM3009, STM5136) to twenty alleles (marker STM0019) were identified. The allele frequencies were from 0.021-0.21 for the STM3012 marker, and 0.08-0.33 for the STM3009 and STM0019 markers (Fig. 2). It was found that the greatest number of alleles - 20 was identified by the marker STM0019, of sizes 98-258 bp. For the markers STM3009 and STM5136, five alleles with size range of 164-172 and 240$267 \mathrm{bp}$ respectively were determined.

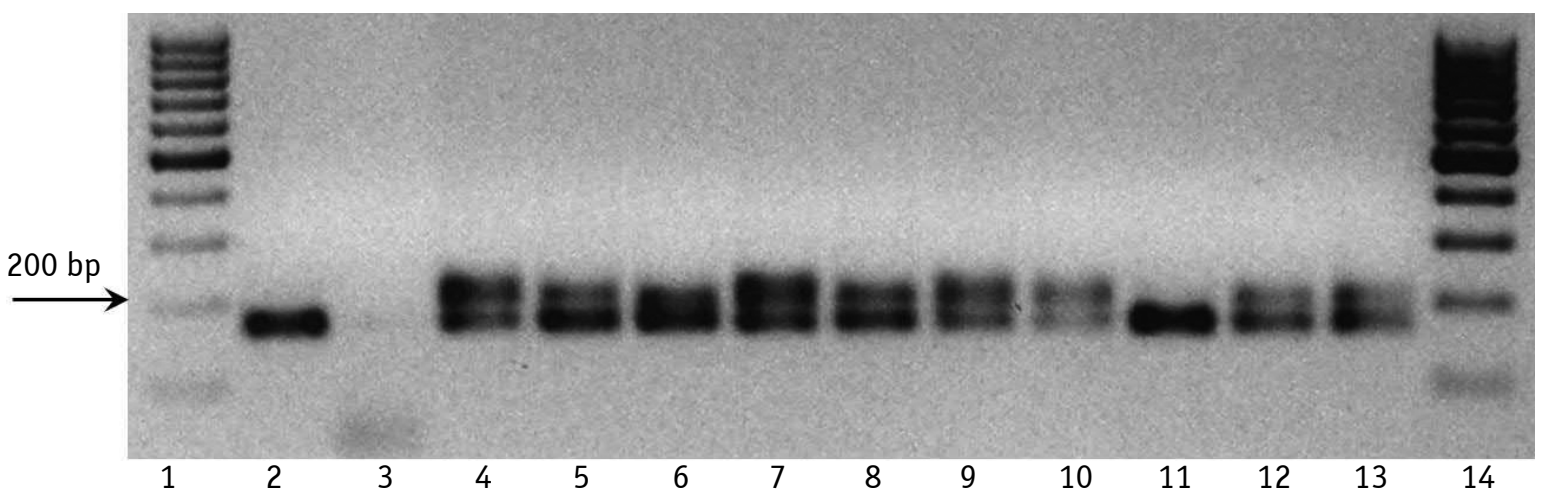

Fig. 1. Electropherogram of DNA amplification products of different potato varieties based on STM3012 marker: 1, 14 - molecular weight marker 100 bp DNA Ladder 0'GeneRuler (Thermo Scientific); 2 - 'Poliske Dzherelo'; 3 - 'Dorohyn'; 4 - 'Okolytsia'; 5 - 'Dovira'; 6 - 'Lileia'; 7 - 'Levada'; 8 - 'Yavir'; 9 - 'Chervona Ruta'; 10 - 'Skarbnytsia'; 11 - '0brii'; 12 - 'Fantaziia'; 13 - 'Slovianka'

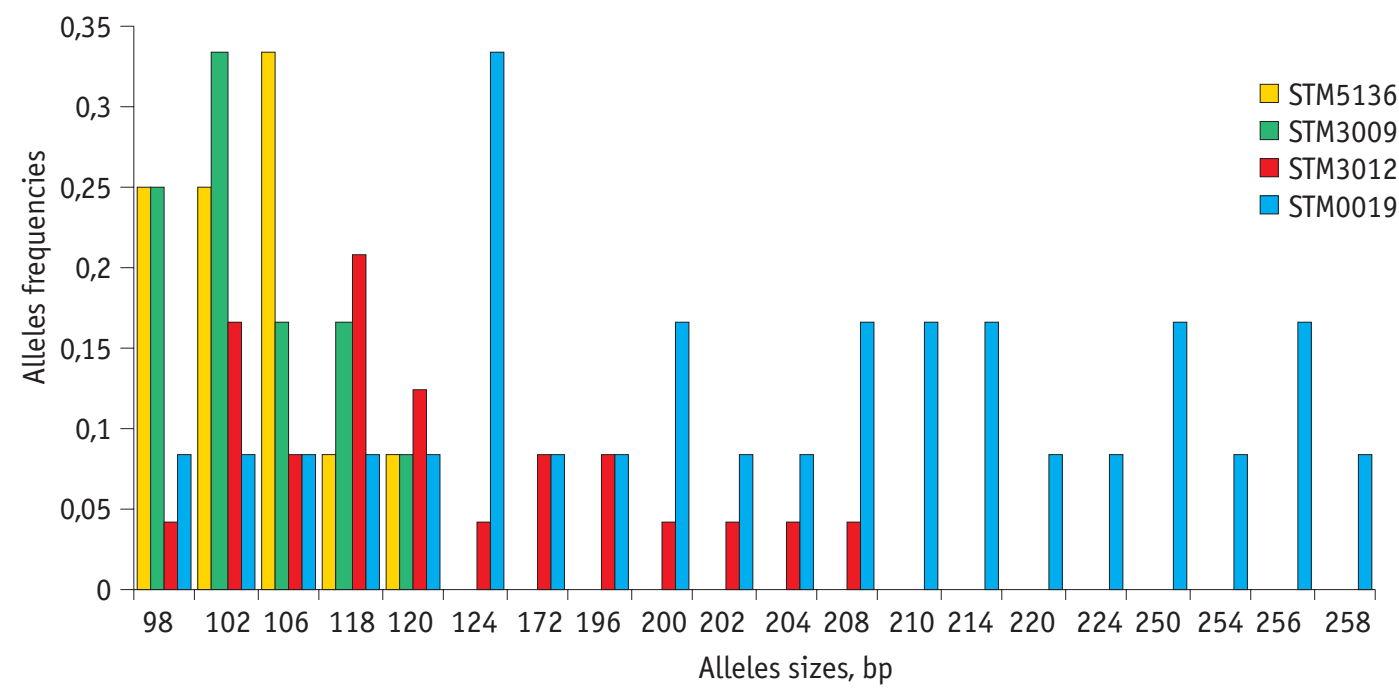

Fig. 2. Distribution of identified alleles by size and frequency for the investigated potato varieties based on STM0019, STM3009, STM3012, STM136 markers

For the studied loci, the average value of the polymorphism index of the locus (RIS) is 0.76 , with the highest index obtained for the marker STM3012 - 0.88. The listed level of PIC indicates a uniform distribution of identified alleles and sufficient resolution for differentiation of investigated potato varieties.

To study the polymorphism of 12 varieties of potatoes based on SSR markers and morpho- logical features, a cluster analysis was performed and genetic distances between varieties were calculated (Fig. 3).

As a result of cluster analysis and calculation of genetic distances between studied potato varieties, the greatest distance was noted between 'Levada' and 'Dovira', 'Fantaziia' and 'Dovira' varieties - 3.74. Considering that with the decrease in the digital value of genetic dis- 


\begin{tabular}{|c|c|c|c|c|c|c|c|c|c|c|c|}
\hline Varieties & Dorohyn & Okolytsia & Dovira & Lileia & Levada & Yavir & Chervona Ruta & Skarbnytsia & Obrii & Fantaziia & Slovianka \\
\hline \multirow{2}{*}{$\begin{array}{l}\text { Poliske Dzherelo } \\
\text { Dorohyn }\end{array}$} & 3,46 & 3,32 & 3,61 & 3,46 & 3,32 & 3,46 & 2,83 & 3,16 & 3,16 & 3,00 & 3,16 \\
\hline & & 3,32 & 3,00 & 3,16 & 3,32 & 3,16 & 3,16 & 2,83 & 3,16 & 3,61 & 3,46 \\
\hline \multirow{2}{*}{$\begin{array}{l}\text { Okolytsia } \\
\text { Dovira }\end{array}$} & & & 3,16 & 3,00 & 3,16 & 3,32 & 3,61 & 3,32 & 3,32 & 3,46 & 3,32 \\
\hline & & & & 3,61 & 3,74 & 2,65 & 3,00 & 3,00 & 3,32 & 3,74 & 3,61 \\
\hline \multirow{2}{*}{$\begin{array}{l}\text { Lileia } \\
\text { Levada }\end{array}$} & & & & & 3,32 & 3,46 & 3,46 & 3,46 & 3,16 & 3,61 & 2,83 \\
\hline & & & & & & 3,61 & 3,32 & 3,61 & 3,32 & 3,46 & 3,61 \\
\hline \multirow{2}{*}{$\begin{array}{l}\text { Yavir } \\
\text { Chervona Ruta }\end{array}$} & & & & & & & 2,83 & 2,45 & 2,83 & 3,61 & 3,16 \\
\hline & & & & & & & & 3,46 & 3,16 & 3,61 & 3,46 \\
\hline \multirow{2}{*}{$\begin{array}{l}\text { Skarbnytsia } \\
\text { Obrii }\end{array}$} & & & & & & & & & 2,83 & 3,61 & 3,16 \\
\hline & & & & & & & & & & 3,00 & 3,16 \\
\hline Fantaziia & & & & & & & & & & & 3,61 \\
\hline
\end{tabular}

Fig. 3. Genetic distances between investigated potato varieties based on SSR markers

(the color reflects genetic distances in descending order where blue (red) denotes large (small) distances, respectively)

tances the affinity between varieties increases, the genotypes with the value of 2.45 - 'Skarbnytsia' and 'Yavir' were the most close ones. Among other varieties, the values of genetic distances ranged from 3.61 to 2.65 .

It is known that objects of cluster analysis with zero values of genetic distances are considered to be identical. Taking into account the obtained data, the studied varieties are different accor- ding to the proposed marker system. Taking into account that the investigated varieties of potatoes are the result of selective work of one institution, the proposed marker system is effective for the differentiation of closely related objects.

According to the set of marker morphological characters of the studied potato varieties, a cluster analysis was performed and genetic distances were calculated (Fig. 4).

\begin{tabular}{|c|c|c|c|c|c|c|c|c|c|c|c|}
\hline Varieties & Dorohyn & 0kolytsia & Dovira & Lileia & Levada & Yavir & Chervona Ruta & Skarbnytsia & Obrii & Fantaziia & Slovianka \\
\hline Poliske Dzherelo & 10,2 & 11,7 & 10,3 & 10,1 & 14,2 & 16,0 & 12,5 & 9,0 & 13,2 & 13,7 & 12,0 \\
\hline Dorohyn & & 13,6 & 13,2 & 13,1 & 14,8 & 17,6 & 15,4 & 12,0 & 14,6 & 15,5 & 13,5 \\
\hline Okolytsia & & & 14,0 & 12,4 & 14,7 & 17,7 & 17,1 & 10,9 & 13,9 & 16,3 & 13,2 \\
\hline Dovira & & & & 9,8 & 12,7 & 13,6 & 10,4 & 11,3 & 10,2 & 12,1 & 12,1 \\
\hline Lileia & & & & & 12,0 & 13,7 & 11,8 & 10,7 & 8,9 & 12,5 & 12,3 \\
\hline Levada & & & & & & 18,2 & 14,6 & 12,5 & 13,6 & 15,6 & 15,6 \\
\hline Yavir & & & & & & & 14,0 & 14,6 & 14,8 & 15,4 & 16,6 \\
\hline Chervona Ruta & & & & & & & & 11,4 & 11,9 & 12,8 & 16,0 \\
\hline Skarbnytsia & & & & & & & & & 12,6 & 12,1 & 12,3 \\
\hline Obrii & & & & & & & & & & 14,2 & 13,0 \\
\hline Fantaziia & & & & & & & & & & & 13,9 \\
\hline
\end{tabular}

Fig. 4. Genetic distances between investigated varieties of potatoes based on morphological markers

(the color reflects genetic distances in descending order where blue (red) denotes large (small) distances, respectively)

The investigation revealed that the most distant by morphological features are 'Okolytsia' and 'Dovira' varieties, the numerical value of which was 18.2. 'Lileia' and 'Dorogyn' with distances of 17.6 and 17.7, respectively, were quite distant from 'Okolytsia'. The most related varieties were 'Slovianka' and 'Poliske Dzherelo' and 'Chervona Ruta' and 'Levada' with values of genetic distances of 8.9 and 9.0. 'Lileia', 'Skarbnytsia' and 'Poliske Dzherelo' were quite close to 'Levada' (10.1-10.3).

Cluster analysis according to selected indicators shows a different distribution of genotypes and their degree of affinity. To determine the objective approaches to the examination of varieties, a complex evaluation of different characteristics is required. The correlation between genetic distances obtained by SSR analysis and morphological features was evaluated using Mantel test (Pearson's correlation) [9]. As a result of the analysis, the pvalue and $\mathrm{r}(\mathrm{AB})$ indices for the significance level $\alpha=0.05$ were determined, which according to the interpretation of the test, allows to accept one of the analysis hypotheses of the presence (Ha) or absence of correlation (H0) (Fig. 5).

According to the analysis, the $\mathrm{HO}$ hypothesis about the absence of correlation is assumed under the condition $\mathrm{p}>\alpha$, that is the calculated value $p=0.765$ significantly exceeds the significance level $\alpha=0.05$.

Therefore, the alternative hypothesis $\mathrm{Ha}$ of the presence of correlation was rejected and the zero hypothesis HO [6, 27-28] was adopted. The correlation coefficient $[\mathrm{r}(\mathrm{AB})]$ and the normality of the data distribution along the matrixes of genetic distances are presented in Figure 6. The diagram form indicates the normality of the data distribution and the reliability of the sample, the correlation coefficient by Mantel was $\mathrm{r}=\mathbf{0 . 0 3 5}$. According to the hypothesis H0, a reliable correlation by the Mantel test between the genetic distances for SSR 


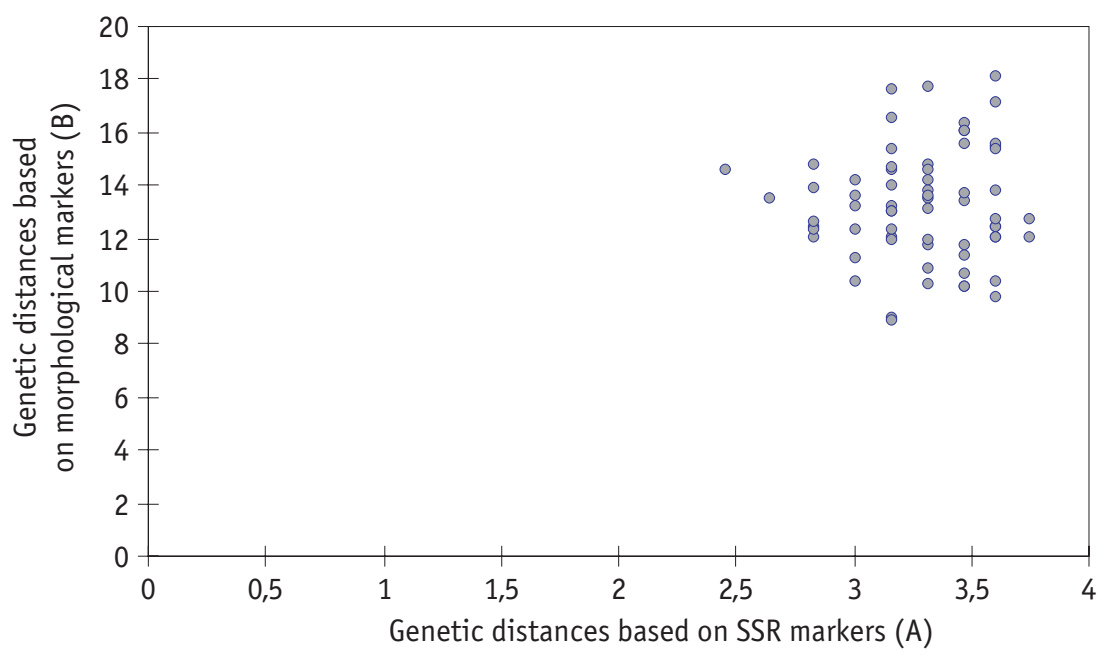

Fig. 5. Correlation between genetic distances based on SSR markers and morphological features of potato varieties

markers and morphological features in the investigated varieties of potatoes was not detected. The results of the absence and presence of correlations between genetic distances were obtained by Karuri H. W. et al. [29] during the study of the genetic diversity of sweet potato varieties, as well as Darvishzadeh R. [30] in the study on sunflower varieties.

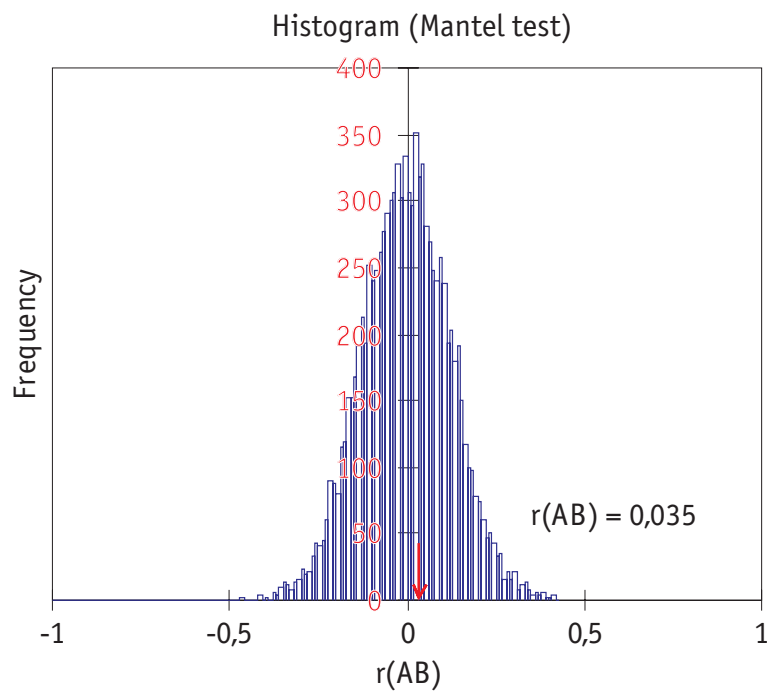

Fig. 6. Results of graphical analysis of data distribution by Mantel test results for potatoes varieties by genetic distances

However, the distribution obtained by genetic distances allowed detecting the difference between the studied potato varieties. Consequently, due to the analysis of genetic distances for the four SSR markers and morphological features, it is determined that the most distant from the two marker systems is 'Dovira variety'. For other studied varieties, differentiation by these criteria varied, which indicates the possibility of applying different approaches to the definition of varietal differences.

\section{Conclusions}

The molecular genetic polymorphism of 12 varieties of potatoes based on four microsatel- lite markers and 42 morphological features used for the description of the variety during the examination on DUS was investigated.

According to the results of the cluster analysis, it was revealed that the varieties 'Skarbnytsia' and 'Yavir' were the most similar by loci STM0019, STM3009, STM3012, STM5136; the genetic distance between them was 2.45 . The obtained results were used to create a database of molecular genetic polymorphisms of the studied potato varieties for further identification.

Regarding the distribution of varieties according to morphological features, it was found that the lowest value of the genetic distance was 8.9 between 'Slovianka' and 'Poliske Dzhe- 
relo'. The most distant, both morphologically and by SSR markers, was 'Dovira' variety with a genetic distance of 18.2 and 3.74, respectively.

Using the Mantel test, it was found that there is no correlation between the genetic distances for SSR analysis and marker morphological features. The results of the assessment of the varieties distribution allow the use of studies containing a description of morphological features and microsatellite markers for the creation of collections of well-known varieties and determination of varietal differences in the process of DUS testing.

\section{References}

1. Bellumori, M., Innocenti, M., Michelozzi, M., Cerretani, L., \& Mulinacci, N. (2017). Coloured-fleshed potatoes after boiling: Promising sources of known antioxidant compounds. J. Food Compos. Anal., 59, 1-7. doi: 10.1016/j.jfca.2017.02.004

2. Oliinyk, T. M., Slobodian, S. 0., \& Hrytsai, R. V. (2012). The use of microsatellite markers for phylogenetic analysis potato varieties of domestic and foreign breeding. Kartopliarstvo [Potato Production], 41, 41-48. [in Ukrainian]

3. Zaviriukha, P., \& Lishchynska, N. (2013). Studying of a initial material for potato breeding on a complex of valuable economic signs. Visnyk Lvivskoho natsionalnoho ahrarnoho universytetu. Ahronomiia [Bulletin of Lviv National Agrarian University. Agronomy], 17(2), 220-232. [in Ukrainian]

4. Chung, Y. S., Palta, J., Bamberg, J., \& Jansky, S. (2016). Potential molecular markers associated with tuber calcium content in wild potato germplasm. Crop Sci., 56(2), 576-584. doi: 10.2135/ cropsci2015.06.0370

5. Ramakrishnan, A. P., Ritland, C. E., Sevillano, R. H. B., \& Riseman, A. (2015). Review of potato molecular markers to enhance trait selection. Am. J. Potato Res., 92(4), 455-472. doi: 10.1007/ s12230-015-9455-7

6. Burstin, J., \& Charcosset, A. (1997). Relationship between phenotypic and marker distances: theoretical and experimental investigations. Heredity, 79(5), 477-483. doi: 10.1038/sj.hdy. 6882270

7. Geng, Y., van Klinken, R. D., Sosa, A., Li, B., Chen, J., \& Xu, C. Y. (2016). The relative importance of genetic diversity and phenotypic plasticity in determining invasion success of a clonal weed in the USA and China. Front. Plant Sci., 7, 213-216. doi: 10.3389/fpls.2016.00213

8. Valliyodan, B., Ye, H., Song, L., Murphy, M., Shannon, J. G., \& Nguyen, H. T. (2016). Genetic diversity and genomic strategies for improving drought and waterlogging tolerance in soybeans. J. Exp. Bot., 68(8), 1835-1849. doi: 10.1093/jxb/erw433

9. Riday, H., Brummer, E. C., Campbell, T. A., Luth, D., \& Cazcarro, P. M. (2003). Comparisons of genetic and morphological distance with heterosis between Medicago sativa subsp. sativa and subsp. falcata. Euphytica, 131(1), 37-45. doi: 10.1023/A:1023050126901

10. Volkova, N. E. (2015). Molecular markers in genetics, breeding and seed production of legumes (review). Zbirnyk naukovykh prats SHI - NTSNS [Collected Scientific Articles of PBGI NCSCI], 26, 99-106. [in Ukrainian]

11. Shen, Z., Zhang, K., Ma, L., Duan, J., \& Ao, Y. (2017). Analysis of the genetic relationships and diversity among 11 populations of Xanthoceras sorbifolia using phenotypic and microsatellite marker data. Electron. J. Biotechnol., 26, 33-39. doi: 10.1016/ j.ejbt.2016.12.008

12. Kwon, Y. S., Lee, J. M., Yi, G. B., Yi, S. I., Kim, K. M., Soh, E. H., ... Kim, B. D. (2005). Use of SSR markers to complement tests of distinctiveness, uniformity, and stability (DUS) of pepper
(Capsicum annuum L.) varieties. Mol. Cells, 19(3), 428-435.

13. Tkachyk, S. 0. (Ed.). (2016). Metodyka provedennia ekspertyzy sortiv roslyn hrupy ovochevykh, kartopli ta hrybiv na vidminnist, odnoridnist $i$ stabilnist [Method of examination of plant varieties of vegetable, potato and mushroom groups for distinctness, uniformity and stability]. Vinnytsia: Nilan-LTD. [in Ukrainian]

14. Côté, M. J., Leduc, L., \& Reid, A. (2013). Evaluation of simple sequence repeat (SSR) markers established in Europe as a method for the identification of potato varieties grown in Canada. Am. J. Potato Res., 90(4), 340-350. doi: 10.1007/ s12230-013-9310-7

15. Tkachyk, S. 0. (Ed.). (2015). Metodyka provedennia kvalifikatsiinoi ekspertyzy sortiv roslyn na prydatnist do poshyrennia $v$ Ukraini. Metody vyznachennia pokaznykiv yakosti produktsii roslynnytstva [Method of conducting qualification examination of plant varieties for suitability of their distribution in Ukraine. Methods of determining the quality indices of crop production]. Vinnytsia: Nilan-LTD. [in Ukrainian]

16. Rocha, E. A., Paiva, L. V., Carvalho, H. H. D., \& Guimarães, C. T. (2010). Molecular characterization and genetic diversity of potato cultivars using SSR and RAPD markers. Crop Breed. Appl. Biotechnol., 10(3), 204-210. doi: 10.1590/S198470332010000300004

17. Ghebreslassie, B. M., Githiri, S. M., Mehari, T., Kasili, R. W., Ghislain, M., \& Magembe, E. (2016). Genetic diversity assessment of farmers' and improved potato (Solanum tuberosum) cultivars from Eritrea using simple sequence repeat (SSR) markers. Afr. J. Biotechnol., 15(35), 1883-1891. doi: 10.5897/AJB2016.15237

18. Reid, A., Hof, L., Felix, G., Rücker, B., Tams, S., Milczynska, E., ... Weitz, A. (2011). Construction of an integrated microsatellite and key morphological characteristic database of potato varieties on the EU common catalogue. Euphytica, 182(2), 239-249. doi: 10.1007/s10681-011-0462-6

19. Reid, A., Hof, L., Esselink, D., \& Vosman, B. (2009). Potato Cultivar Genome Analysis. In R. Burns (Ed.), Plant Pathology. Methods in Molecular Biology (Vol. 508, pp. 295-308). New York, N.Y.: Humana Press. doi: 10.1007/978-1-59745-062-1_2

20. Roik, M. V., Syvolap, Yu. M., Petiukh, H. P., Shaiuk, L. V., Babiazh, A. I., \& Bilous, N. V. (2007). Vyznachennia molekuliarnohenetychnoho polimorfizmu rodu Beta L. za dopomohoiu polimeraznoi lantsiuhovoi reaktsii [Detection of moleculargenetic polymorphism of the genus Beta L. by polymerase chain reaction]. Kyiv: PolihrafKonsaltynh. [in Ukrainian]

21. Fortin, M. J., Dale, M. R., \& Ver Hoef, J. M. (2002). Spatial analysis in ecology. In A. H. El-Shaarawi, \& W. W. Piegorsch (Eds.), Encyclopedia of Environmetrics (Vol. 4, pp. 2051-2058). Chichester: John Wiley \& Sons Ltd.

22. Drozdov, V. I. (2010). Instruktsiya po ispolzovaniyu paketa Statistica 6.0 [Manual for using Statistica 6.0]. Kursk: Izdatelstvo YuZGU. [in Russian]

23. Everitt, B. S., Landau, S., Leese, M., \& Stahl, D. (2011). Cluster Analysis. ( $5^{\text {th }}$ ed.). Chichester: John Wiley \& Sons Ltd. doi: 10.1002/9780470977811

24. Kishine, M., Tsutsumi, K., \& Kitta, K. (2017). A set of tetranucleotide core motif SSR markers for efficient identification of potato (Solanum tuberosum) cultivars. Breed. Sci., 67(5), 544-547. doi: 10.1270/jsbbs.17066

25. Legendre, P., \& Fortin, M. J. (2010). Comparison of the Mantel test and alternative approaches for detecting complex multivariate relationships in the spatial analysis of genetic data. Mol. Ecol. Resour., 10(5), 831-844. doi: 10.1111/j.17550998.2010.02866.x

26. Diniz-Filho, J. A. F., Soares, T. N., Lima, J. S., Dobrovolski, R., Landeiro, V. L., Telles, M. P. D. C., ... Bini, L. M. (2013). Mantel test in population genetics. Genet. Mol. Biol., 36(4), 475-485. doi: $10.1590 /$ S1415-47572013000400002

27. Zhang, Q., Peters, J. L., Visser, E. J., Kroon, H., \& Huber, H. (2016). Hydrologically contrasting environments induce genetic but 
not phenotypic differentiation in Solanum dulcamara. J. Ecol., 104(6), 1649-1661. doi: 10.1111/1365-2745.12648

28. Muhinyuza, J. B., Shimelis, H., Melis, R., Sibiya, J., Gahakwa, D., \& Nzaramba, M. N. (2015). Assessment of genetic relationship of promising potato genotypes grown in Rwanda using SSR markers. Aust. J. Crop Sci., 9(8), 696-700.

29. Karuri, H. W., Ateka, E. M., Amata, R., Nyende, A. B., Muigai, A. W. T., Mwasame, E., \& Gichuki, S. T. (2010). Evaluating diversity among Kenyan sweet potato genotypes using morphological and SSR markers. Int. J. Agr. Biol., 12(1), 33-38.

30. Darvishzadeh, R. (2012). Phenotypic and molecular marker distance as a tool for prediction of heterosis and $F_{1}$ performance in sunflower (Helianthus annuus L.) under well-watered and water-stressed conditions. Aust. J. Crop Sci., 6(4), 732-738.

\section{Використана література}

1. Bellumori M., Innocenti M., Michelozzi M. et al. Colouredfleshed potatoes after boiling: Promising sources of known antioxidant compounds. J. Food Compos. Anal. 2017. Vol. 59. P. 1-7. doi: 10.1016/j.jfca.2017.02.004

2. Олійник Т. М., Слободян С. 0., Грицай Р. В. Застосування мікросателітних маркерів картоплі для філогенетичного аналізу сортів вітчизняної та зарубіжної селекції. Картоплярство. 2012. Вип. 41. С. 41-48.

3. Завірюха П., Ліщинська Н. Вивчення вихідного матеріалу для селекції картоплі на комплекс цінних господарських ознак. Вісн. Львів. нац. аграр. ун-ту. Сер.: Агрономія. 2013. № 17(2). C. 220-232.

4. Chung Y. S., Palta J., Bamberg J., Jansky S. Potential molecular markers associated with tuber calcium content in wild potato germplasm. Crop Sci. 2016. Vol. 56, No. 2. P. 576-584. doi: 10.2135/cropsci2015.06.0370

5. Ramakrishnan A. P., Ritland C. E., Sevillano R. H. B., Riseman A. Review of potato molecular markers to enhance trait selection. Am. J. Potato Res. 2015. Vol. 92, Iss. 4. P. 455-472. doi: 10.1007/ s12230-015-9455-7

6. Burstin J., Charcosset A. Relationship between phenotypic and marker distances: theoretical and experimental investigations. Heredity. 1997. Vol. 79, No. 5. P. 477-483. doi: 10.1038/sj.hdy. 6882270

7. Geng Y., van Klinken R. D., Sosa A. et al. The relative importance of genetic diversity and phenotypic plasticity in determining invasion success of a clonal weed in the USA and China. Front. PlantSci.2016.Vol. 7. P. 213-216. doi:10.3389/fpls.2016.00213

8. Valliyodan B., Ye H., Song L. et al. Genetic diversity and genomic strategies for improving drought and waterlogging tolerance in soybeans. J. Exp. Bot. 2016. Vol. 68, Iss. 8. P. 1835-1849. doi: $10.1093 / \mathrm{jxb} / \mathrm{erw} 433$

9. Riday H., Brummer E. C., Campbell T. A. et al. Comparisons of genetic and morphological distance with heterosis between Medicago sativa subsp. sativa and subsp. falcata. Euphytica. 2003. Vol. 131, Iss. 1. P. 37-45. doi: 10.1023/A:1023050126901

10. Волкова Н. Е. Молекулярні маркери в генетиці, селекції та насінництві бобових культур (огляд). Збірник наук. праць СГІ-НЦНС. 2015. Вип. 26. С. 99-106.

11. Shen Z., Zhang K., Ma L. Analysis of the genetic relationships and diversity among 11 populations of Xanthoceras sorbifolia using phenotypic and microsatellite marker data. Electron. J. Biotechnol. 2017. Vol. 26. P. 33-39. doi: 10.1016/ j.ejbt. 2016.12.008

12. Kwon Y. S., Lee J. M., Yi G. B. et al. Use of SSR markers to complement tests of distinctiveness, uniformity, and stability (DUS) of pepper (Capsicum annuum L.) varieties. Mol. Cells. 2005. Vol. 19, No. 3. P. 428-435.

13. Методика проведення експертизи сортів рослин групи овочевих, картоплі та грибів на відмінність, однорідність і стабільність / за ред. С. 0. Ткачик. Вінниця : Нілан-ЛТД, 2016. 1144 c.
14. Côté M.-J., Leduc L., Reid A. Evaluation of Simple Sequence Repeat (SSR) Markers Established in Europe as a Method for the Identification of Potato Varieties Grown in Canada. Am. J. Potato Res. 2013. Vol. 90, Iss. 4. P. 340-350. doi: 10.1007/ s12230-013-9310-7

15. Методика проведення кваліфікаційної експертизи сортів рослин на придатність до поширення в Україні. Методи визначення показників якості продукції рослинництва / за ред. С. 0. Ткачик. Вінниця : Нілан-ЛТД, 2015. 160 с.

16. Rocha E. A., Paiva L. V., Carvalho H. H. D., Guimarres C. T. Molecular characterization and genetic diversity of potato cultivars using SSR and RAPD markers. Crop Breed. Appl. Biotechnol. 2010. Vol. 10, No. 3. P. 204-210. doi: 10.1590/ S1984-70332010000300004

17. Ghebreslassie B. M., Githiri S. M., Mehari T. Genetic diversity assessment of farmers' and improved potato (Solanum tuberosum) cultivars from Eritrea using simple sequence repeat (SSR) markers. Afr. J. Biotechnol. 2016. Vol. 15, No. 35. P. 1883-1891. doi: 10.5897/AJB2016.15237

18. Reid A., Hof L., Felix G. et al. Construction of an integrated microsatellite and key morphological characteristic database of potato varieties on the EU common catalogue. Euphytica. 2011. Vol. 182, Iss. 2. P. 239-249. doi: 10.1007/s10681-0110462-6

19. Reid A., Hof L., Esselink D., Vosman B. Potato cultivar genome analysis. Plant Pathology. Methods in Molecular Biology / R. Burns (ed.). New York, N.Y. : Humana Press, 2009. Vol. 508. P. 295-308. doi: 10.1007/978-1-59745-062-1_2

20. Роїк М. В., Сиволап Ю. М., Петюх Г. П. та ін. Визначення молекулярно-генетичного поліморфізму роду Beta L. за допомогою полімеразної ланцюгової реакції. Київ : ПоліграфКонсалтинг, 2007. 27 с.

21. Fortin M. J., Dale M. R., Ver Hoef J. M. Spatial analysis in ecology. Encyclopedia of Environmetrics / A. H. El-Shaarawi and W. W. Piegorsch (eds), Chichester : John Wiley \& Sons Ltd, 2002. Vol. 4, pp. 2051-2058.

22. Дроздов В. И. Инструкция по использованию пакета Statistica 6.0. Курск : Изд-во ЮЗГУ, 2010. 74 с.

23. Everitt B. S., Landau S., Leese M., Stahl D. Cluster Analysis. $5^{\text {th }}$ ed. Chichester : John Wiley \& Sons Ltd, 2011. 346 p. doi: 10.1002/9780470977811

24. Kishine M., Tsutsumi K., Kitta K. A set of tetra-nucleotide core motif SSR markers for efficient identification of potato (Solanum tuberosum) cultivars. Breed. Sci. 2017. Vol. 67, Iss. 5. P. 544-547. doi: $10.1270 /$ jsbbs. 17066

25. Legendre P., Fortin M. J. Comparison of the Mantel test and alternative approaches for detecting complex multivariate relationships in the spatial analysis of genetic data. Mol. Ecol. Resour. 2010. Vol. 10, Iss. 5. P. 831-844. doi: 10.1111/j.17550998.2010.02866.x

26. Diniz-Filho J. A. F., Soares T. N., Lima J. S. et al. Mantel test in population genetics. Genet. Mol. Biol. 2013. Vol. 36, Iss. 4. P. 475-485. doi: 10.1590/S1415-47572013000400002

27. Zhang Q., Peters J. L., Visser E. J. et al. Hydrologically contrasting environments induce genetic but not phenotypic differentiation in Solanum dulcamara. J. Ecol. 2016. Vol. 104, Iss. 6. P. 1649-1661. doi: 10.1111/1365-2745.12648

28. Muhinyuza J. B., Shimelis H., Melis R. et al. Assessment of genetic relationship of promising potato genotypes grown in Rwanda using SSR markers. Aust. J. Crop Sci. 2015. Vol. 9, Iss. 8. P. 696-700.

29. Karuri H. W., Ateka E. M., Amata R. et al. Evaluating diversity among Kenyan sweet potato genotypes using morphological and SSR markers. Int. J. Agr. Biol. 2010. Vol. 12, Iss. 1. P. 33-38.

30. Darvishzadeh R. Phenotypic and molecular marker distance as a tool for prediction of heterosis and $F_{1}$ performance in sunflower (Helianthus annuus L.) under well-watered and water-stressed conditions. Aust. J. Crop Sci. 2012. Vol. 6, Iss. 4. P. 732-738. 
УДК 633.491.577.213.3

Присяжнюк Л. М. ${ }^{*}$, Кляченко 0. Л. ${ }^{2}$, Діхтяр I. 0. ${ }^{1}$, Симоненко Н. В. ${ }^{1}$ Аналіз різноманіття та генетичних взаємодій сортів картоплі (Solanum tuberosum L.) на основі морфологічних ознак та SSR-маркерів. Plant Varieties Studying and Protection. 2018. T. 14, № 3. C. 277-284. https://doi.org/10.21498/2518-1017.14.3.2018.145292

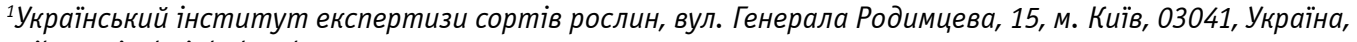
"e-mail: prysiazhniuk_l@ukr.net

${ }^{2}$ Національний університет біоресурсів і природокористування України, вул. Героїв Оборони, 15, м. Київ, 03041, Україна

Мета. Оцінити кореляційні зв'язки між SSR-маркерами та морфологічними ознаками за генетичними дистанціями на основі поліморфізму сортів картоплі. Методи. ПЛР-аналіз, кластерний та кореляційно-регресійний аналізи. Результати. Наведено результати аналізу поліморфізму сортів картоплі за молекулярно-генетичними та морфологічними маркерними ознаками. Поліморфізм сортів оцінювали за чотирма мікросателітними маркерами: STM0019, STM3009, STM3012, STM5136 та за 42 морфологічними маркерними ознаками. За результатами ПЛР-аналізу визначено, що частота ідентифікованих алелів становила від 0,021 до 0,33, індекс полімофності в середньому за досліджуваними маркерами - 0,76. За допомогою кластерного аналізу визначено генетичні дистанції між сортами за SSR- та морфологічними маркерами, виявлено подібні та сорти, які різнилися між собою. Відповідно до отриманого розподілу оцінено кореляційні зв'язки між генетичними дистанціями за Mantel test, а саме визначено регресію, в якій змінними $€$ матриці подібності, що підсумовують попарні подібні значення між місцями вибірки. Унаслідок оцінювання генетичних дистанцій між дослідженими генотипами картоплі встановлено, що найподібнішими за маркерами STM0019, STM3009, STM3012, STM5136 виявилися сорти 'Скарбниця' та 'Явір', відстань між якими становила 2,45, тоді як найбільшу відстань - 3,74 виявлено між сортами 'Левада' та 'Довіра', 'Фантазія' та 'Довіра'. За маркерними морфологічними ознаками найменше значення генетичних дистанцій $-8,9$ спостерігалося для сортів 'Слов'янка' та 'Поліське джерело', найвіддаленішими виявилися 'Околиця' та 'Довіра', значення для яких становить 18,2. Встановлено, що сорт картоплі 'Довіра' зі значенням показників генетичних дистанцій 18,2 та 3,74 за морфологічними та SSR-маркерами відповідно виявився найвіддаленішим від інших досліджених генотипів. У результаті проведеного аналізу генетичних дистанцій за SSR-маркерами та морфологічними ознаками кореляційних зв'язків за Mantel test не виявлено. Висновки. Застосування комплексу досліджень, які містять опис морфологічних ознак і мікросателітних маркерів $\epsilon$ перспективним для ідентифікації сортів картоплі, створення колекцій загальновідомих сортів та визначення їх відмінностей.

Ключові слова: картопля; генетичний поліморфізм; кластерний аналіз; Mantel test; кореляційні зв'язки.

УДК 633.491.577.213.3

Присяжнюк Л. М. ${ }^{*}{ }^{*}$, Кляченко 0. Л. ${ }^{2}$, Дихтяр И. А. ${ }^{1}$, Симоненко Н. В. ${ }^{1}$ Анализ разнообразия и генетических взаимодействий сортов картофеля (Solanum tuberosum L.) на основе морфологических признаков и SSR-маркеров // Plant Varieties Studying and Protection. 2018. T. 14, № 3. C. $277-284$.

https://doi.org/10.21498/2518-1017.14.3.2018.145292

'Украинский институт экспертизы сортов растений, ул. Генерала Родимцева, 15, 2. Киев, 03041, Украина, *e-mail: prysiazhniuk_l@ukr.net

${ }^{2}$ Национальный университет биоресурсов и природопользования Украины, ул. Героев Обороны, 15, г. Киев, 03041, Украина

Цель. Оценить корреляционные связи между SSRмаркерами и морфологическими признаками по генетическим дистанциям на основе полиморфизма сортов картофеля. Методы. ПЦР анализ, кластерный и корреляционно-регрессионный анализы. Результаты. Приведены результаты анализа полиморфизма сортов картофеля по молекулярно-генетическим и морфологическим маркерным признакам. Полиморфизм сортов картофеля оценивали по четырем микросателлитным маркерам: STM0019, STM3009, STM3012, STM5136 и 42 морфологическим маркерными признакам. По результатам ПЦР-анализа определено, что частота идентифицированных аллелей составляла от 0,021 до 0,33, индекс полимофности локуса в среднем по исследованным маркерам - 0,76. С помощью кластерного анализа определены генетические дистанции между сортами по SSR- и морфологическим маркерам, отмечены сходные и различные сорта. В соответствии с полученным распределением проведена оценка корреляционных связей между генетическими дистанциями по Mantel test, а именно определена регрессия, в которой переменными выступают матрицы сходства, которые суммируют попарные сходные значения между местами выборки. В результате оценки генетических дистанций между исследованными геноти- пами картофеля установлено, что наиболее сходными по маркерам STM0019, STM3009, STM3012, STM5136 оказались сорта 'Скарбныця' и 'Явир', расстояние между которыми составляло 2,45, тогда как наибольшее расстояние - 3,74 отмечено между сортами 'Левада' и 'Довира', 'Фантазия' и 'Довира'. По маркерным морфологическим признакам наименьшее значение генетических дистанций - 8,9 наблюдалось для сортов 'Славянка' и 'Полиське джерело', отдаленными оказались '0колыця' и 'Довира', значение для которых составляет 18,2. Установлено, что сорт картофеля 'Довира' со значением показателей генетических дистанций 18,2 и 3,74 по морфологическим и SSR-маркерами соответственно оказался самым удаленным от других исследованных генотипов. В результате проведенного анализа генетических дистанций по SSR-маркерам и морфологическим признакам корреляционных связей по Mantel test не обнаружено. Выводы. Применение комплекса исследований, включающих описание морфологических признаков и микросателлитных маркеров является перспективным для идентификации сортов картофеля, создание коллекций общеизвестных сортов и определения их различий.

Ключевые слова: картофель; генетический полиморфизм; кластерный анализ; Mantel test; корреляционные связи.

Надійшла / Received 06.07.2018

Погоджено до друку / Accepted 04.09.2018 